\title{
Can We Trust Financial Analysts? Reliability of Stock Recommendations and Firm-Specific Characteristics
}

\author{
Pierluigi Santosuosso ${ }^{1}$ \\ ${ }^{1}$ School of Economics, Sapienza University of Rome, Rome, Italy \\ Correspondence: Pierluigi Santosuosso, School of Economics, Sapienza University of Rome, Rome, Italy. Tel: \\ 39-6-4976-6460. E-mail: pierluigi.santosuosso@uniroma1.it
}

Received: June 29, 2015

Accepted: July 11, 2015

Online Published: August 25, 2015

doi:10.5539/ijef.v7n9p313

URL: http://dx.doi.org/10.5539/ijef.v7n9p313

\begin{abstract}
We examine the reliability of analysts' stock recommendations issued for Italian listed firms by exploring absolute stock returns. Research findings reveal that absolute stock returns following recommendations differ depending on whether they are positive, neutral or negative recommendations, but slightly more than fifty percent of recommendations are confirmed by absolute stock returns. On the basis of the logistic regression model, we also document that the reliability of stock recommendations is inversely connected to the uncertainty faced by investors who hold stocks in a specific firm, as suggested by the estimate of explanatory variables, such as the firm's beta, the interest coverage ratio and cash flow volatility.
\end{abstract}

Keywords: stock recommendations, absolute stock returns, financial analysts, Italian listed firms, forecast accuracy

\section{Introduction}

Stock recommendations published by brokerage houses provide a rare opportunity for examining an unequivocal course of action (Elton, Gruber, \& Grossman, 1986). Although stock recommendations are officially distributed to professional investors, there is no doubt that stock rating systems used by brokerage houses, such as "Buy" or "Sell" recommendations, provide a clear indication for investment decisions. Nonprofessional investors can be particularly subject to recommendations of financial analysts. The limited skills of some investors have been underlined by several studies which have shown that small investors tend to take recommendations literally (Malmendier \& Shanthikumar, 2007) and respond merely to the issuance of stock recommendations (Mikhail, Walther, \& Willis, 2007). Such rating systems implicitly assume the existence of unsophisticated investors since professional investors are more interested in information rather than recommendations. Two main questions related to this topic are addressed in this paper.

First, do absolute stock returns confirm stock recommendations? Unlike the methodologies used by previous research, we use the absolute stock return to assess the reliability of analysts' stock recommendations issued by brokerage houses. To illustrate the relevance of absolute stock returns, assume that the return on a stock for a period of one year is $-5 \%$. If the return of the market is $-7 \%$, the stock would have an ex post abnormal return of $2 \%$. The positive abnormal return of $2 \%$ certainly does not meet the expectations of some investors since the absolute stock return of $-5 \%$ could be lower than the required return of other investments with similar risks and certainly lower than the return on an investment with no risk of financial loss. Similarly, if the annual return on a stock is $12 \%$ and the return of the market is $14 \%$, the stock would have an ex post abnormal return of $-2 \%$. The absolute stock return of $12 \%$ could, however, be higher than the required return of other investments with similar risks. The analysis of absolute stock returns can facilitate the decision-making of investors who are not interested and/or do not have the expertise and resources for measuring stock returns on the basis of various indicators, such as the abnormal stock return, calculated by subtracting market performances or other benchmarks from a single stock or portfolio return. For the purposes of this study, we called this type of private or business investors "nonprofessional and unsophisticated investors" (hereafter, unsophisticated investors).

Second, which firm-specific characteristics can explain the reliability of stock recommendations? The level of reliability of stock recommendations for each company should presumably vary because of the many circumstances that can affect analysts' forecasts. We highlight this issue by examining the role of various explanatory variables, including some firm-specific characteristics. In particular, without formulating a priori 
specific hypotheses, we assume the existence of relationships between the reliability of stock recommendations and some stock market indicators, proxies of financial risk, firm size and firm profitability. Using a sample of 5,443 analysts' stock recommendations issued for Italian listed firms, empirical tests revealed the existence of a significant negative correlation between the level of reliability for each firm of our sample and the firms' beta. Our findings indicate also a positive correlation between the level of reliability of a subsample of 130 non-financial firms and the interest coverage ratio, whilst a negative association was found between the level of reliability and cash flow volatility.

The remainder of this article is organized as follows: the second section presents a brief review of the related literature, the third section describes how the firm sample was selected and the survey methodology; the fourth section reports on the results; the last section provides some concluding remarks.

\section{Literature Review}

A large number of studies have examined the extent of the impact of buy and sell recommendations on stock prices in order to investigate capital market efficiency. Although some researchers have suggested that investors cannot benefit from analysts' recommendations (e.g., Logue \& Tuttle, 1973; Bidwell, 1977; Menendez-Requejo, 2005; Erdogan, Palmon, \& Yezegel, 2011), numerous analyses have documented a significant price reaction to stock recommendations by exploring the existence of abnormal stock returns (Womack, 1996; Barber, Lehavy, McNichols, \& Trueman, 2001; Jegadeesh, Kim, Krische, \& Lee, 2004; Lidèn, 2007). Several specific aspects of this issue have been addressed, such as stock price reactions to recommendation revisions (Ivković \& Jegadeesh, 2004; Elton, Gruber, \& Grossman., 1986; Jegadeesh \& Kim, 2006; Chang \& Chan, 2008), the difference between returns on initiating and continuing recommendations (Chan, Brown, \& Ho, 2006), abnormal returns subsequent to stock recommendations released to a limited clientele (Schlumpf, Schmid, \& Zimmermann, 2008), stock rating distributions over time for the prediction of future recommendations (Barber, Lehavy, McNichols, \& Trueman, 2006) and various determinants of stock recommendations that affect price performance, including the strength of the recommendation, the analysts' reputations and the size of the brokerage house (Stickel, 1995). Research literature have furthermore explored effects of stock recommendations on different phenomena, such as brokerage firm trading (Irvine, 2004), earnings management (Abaranell \& Lehavy, 2003) and the tendency of analysts to follow consensus forecasts according to the "herd behaviour" phenomenon (Jegadeesh \& Kim, 2010; Lin, Chen, \& Chen, 2011). Although several aspects of market reactions and other effects of stock recommendations have been analyzed, the absolute stock return that follows recommendations published by brokerage houses remains largely unexplored.

Similarly, there has been little discussion about how the reliability of stock recommendations is affected by firm-specific characteristics. In particular, two main research areas related to this topic have been explored by empirical studies. First, numerous analyses have examined the impact of several factors on earning forecast accuracy rather than on stock recommendations. To name just a few, the issue has been examined by exploring how the accuracy of analysts' earnings forecasts has been affected by a change of chief executive officer (Choi, Chen, Wright, \& Wu, 2014), the model of reporting firms' primary operating assets (Liang \& Riedl, 2014), the geographical proximity of financial analysts to hubs of information (Cavezzali, Crepaldi, \& Rigoni, 2014), investor expectations (Walther, 2013), strategic patterns of internationalization (Mauri, Lin, \& De Figueiredo, 2013), non-financial disclosure (Dhaliwal, Radhakrishnan, Tsang, \& Yang, 2012), CEO stock options (Kanagaretnam, Lobo, \& Mathieu, 2012), change in the composition and ability of analysts (Nowland \& Simon, 2010), the affiliation of analysts to investment banks or to other institutions (Jacob, Rock, \& Weber, 2008) and corporate transparency (Chiang \& Chia, 2005). And, more closely related to our study, some researchers have examined how firm-specific characteristics affect the accuracy of earnings forecasts. In particular, Parkash, Dhaliwal and Salatka (1995) suggested that the accuracy of earnings forecast is positively associated with the proxies of business risk, financial risk and ownership concentration and negatively correlated to the information index of the firm, measured by firm size and the number of analysts studying a firm. Moreover, Jaggi and Jain (1998) found that earnings forecasts are more accurate with short time horizons and that the beta coefficient and industry classification do not have a significant explanatory power on the accuracy of analyst forecasts.

Second, stock recommendations have been expressly analysed in connection with phenomena that are only marginally related to our research questions. In particular, an issue that has dominated the field concerns how earning forecasts are reflected in stock recommendations. Although several studies have highlighted the existence of a positive influence especially for long-term forecasts (e.g., Bandyopadhyay, Brown, \& Richardson, 1995; Lustgarten \& Tag, 2008; Bradshaw, 2002; Chen \& Chen, 2009; Loh, \& Mian, 2006), it was also found that there is little evidence that stock recommendations and earnings forecasts are related to each other (e.g., Francis \& Soffer, 1997; Bradshaw, 2004; Barniv, Hope, Myring, \& Thomas, 2010). The association between earnings 
forecasts and recommendations has also been studied in the presence of some determinants such as analysts' conflict of interest and analysts' expertise (Ertimur, Sunder, \& Sunder, 2008). Other factors have been analysed in connection with stock recommendations, such as the type of analysts' affiliation (Lin \& McNichols, 1998; Michaely \& Womak, 1999), the conflict of interest between a proprietary trading division and a brokerage division (Shen \& Chih, 2009), the role of analyst optimism (Mokoaleli-Mokoteli, Taffler, \& Agarwal, 2009) and the investor sentiment (Bagnoli, Clement, Crawley, \& Watts, 2009).

\section{Firm Sample and Methodology}

The sample examined in this study contains 5,443 stock recommendations issued for 154 companies listed on the Italian stock exchange (Borsa Italiana) between 2009 and 2013. Stock recommendations, except in a few cases, are written in English and were downloaded directly from the Italian stock exchange's website (Borsa Italiana, 2014) and individually analyzed. More specifically, the sample selection was made on the basis of the following criteria. Firms were included in the sample if brokerage houses covered each company for at least three years in the period between 2009 and 2013. 161 firms did not match this criterion, of which 53 companies were not rated and 108 companies were not covered sufficiently over the period 2009-2013. By examining the stock recommendations individually, the analysts' ratings were classified into three main groups: positive recommendations (buy, outperform, accumulate, add, underweight, undervalued), neutral recommendations (neutral, hold, in line) and negative recommendations (sell, underperform, reduce). Table 1 shows the sample of stock recommendations according to the above-mentioned classification criteria.

Table 1. Sample of stock recommendations

\begin{tabular}{cccccccc}
\hline Years & \multicolumn{2}{c}{ Positive } & \multicolumn{2}{c}{ Neutral } & \multicolumn{2}{c}{ Negative } & Total \\
\hline & Unit & $\%$ & Unit & $\%$ & Unit & $\%$ & Unit \\
2013 & 476 & $58.05 \%$ & 258 & $31.46 \%$ & 86 & $10.49 \%$ & 820 \\
2012 & 670 & $64.49 \%$ & 297 & $28.59 \%$ & 72 & $6.93 \%$ & 1039 \\
2011 & 802 & $63.30 \%$ & 366 & $28.89 \%$ & 99 & $7.81 \%$ & 1267 \\
2010 & 644 & $60.02 \%$ & 331 & $30.85 \%$ & 98 & $9.13 \%$ & 1073 \\
2009 & 648 & $52.09 \%$ & 447 & $35.93 \%$ & 149 & $11.98 \%$ & 1244 \\
Total & 3240 & & 1699 & & 504 & & 5443 \\
\hline
\end{tabular}

In order to ascertain the ability of stock recommendations to predict stock prices, the present paper compared analysts' ratings with the absolute stock returns. More specifically, for each stock recommendation, the analysis was articulated on the basis of the following stages. First, we calculated the average stock price $\mathrm{M}_{0}$ for five days around the date of publication $t=0$ of each stock recommendation, from day $t=-2$ to day $t=2$. Second, we computed the average stock price $\mathrm{M}_{1}$ from the day of publication $t=0$ to the day of the subsequent stock recommendation provided by the same brokerage house. If the subsequent recommendation was absent, the average was calculated over a period of twelve months or for a shorter period if stock prices were not available. Third, we computed the absolute stock returns as $\left(\mathrm{M}_{1}-\mathrm{M}_{0}\right) / \mathrm{M}_{0}$ in order to verify whether the positive and the negative stock recommendations were confirmed by stock returns. More specifically, stock recommendations were considered reliable if $\left(\mathrm{M}_{1}-\mathrm{M}_{0}\right) / \mathrm{M}_{0}>0$ for positive recommendations and $\left(\mathrm{M}_{1}-\mathrm{M}_{0}\right) / \mathrm{M}_{0}<0$ for negative recommendations. We did not consider stock recommendations classified as "neutral" since their information content does not provide a clear indication for the future stock price.

The ability of stock recommendations to predict stock prices over the period 2009-2013 allows us to identify a level of reliability for each firm. The level of reliability was obtained by dividing the number of reliable positive and negative recommendations for a firm by the total number of positive and negative recommendations issued for the same firm. The level of reliability $\mathrm{LR}_{\mathrm{i}}$ is formally described as:

$$
L R_{i}=\left(R P R_{i}+R N R_{i}\right) /\left(T P R_{i}+T N R_{i}\right)
$$

where $R P R_{i}$ is the number of reliable positive recommendations, $R_{N R}$ is the number of reliable negative recommendations, $\mathrm{TPR}_{\mathrm{i}}$ is the total number of positive recommendations and $\mathrm{TNR}_{\mathrm{i}}$ is the total number of negative recommendations issued for each firm.

The correlation between the level of reliability of stock recommendations and some potential explanatory variables was therefore tested using the logistic regression model. More specifically, this study has divided the firm sample into two groups: firms which have stock recommendations with a high level of reliability and firms which have recommendations with a low level of reliability. We supposed that firms belonging to the first group 
are above the median of the level of reliability, whilst firms of the second group are below the median. This paper assumes the binary dependent variable $\mathrm{Y}$ (firms with reliable stock recommendations $\mathrm{Y}=1$; firms with unreliable stock recommendations $\mathrm{Y}=0$ ) and several average market indicators and financial ratios over the period 2009-2013 as independent variables $x_{p}$ using the logistic regression model. Assuming $p=P(Y=1)$, the model has the following general form:

$$
\operatorname{logit}(p)=\log (p /(1-p))=\beta_{0}+\beta_{1} x_{1}+\beta_{2} x_{2}+\ldots+\beta_{p} x_{p}
$$

where $\log (p /(1-p))$ is the natural logarithm of the odds, $p$ is the probability between 0 and 1 that the dependent variable occurs, $\beta_{p}$ is the pth parameter of the logistic regression model obtained by the method of maximum likelihood and $x_{p}$ is the pth explanatory variable.

According to this procedure, three main sets of explanatory variables were examined. The first set is derived from stock markets: the logarithm of the daily average stock trading volume (LogSTV) for the period covered by brokerage houses, the firm's beta (Beta) and the number of analysts that covered each firm (NA). The number of analysts can be used as proxy of the amount of information available about a firm (Parkash, Dhaliwal, \& Salatka, 1995; Ertimur, Sunder, \& Sunder, 2007) and therefore interpreted as a factor that could reduce ceteris paribus the uncertainty faced by investors who hold stocks in a specific firm.

The second group of variables are proxies of firm size and profitability. We used the average value of the following variables for the period covered by brokerage houses: the logarithm of book value of total assets $(\log T A)$, the return on assets ratio (ROA) and the market to book ratio (MB). To avoid the problem of multicollinearity, we excluded measures of firm profitability from our model, such as ROS (return on sale), ROI (return on investment), ROTA (EBIT to total assets) and the asset turnover ratio (revenues to assets). As in the aforementioned case of the number of analysts covering the company, proxies of firm size have also been considered by some studies as factors that increase the amount of information available about a firm (for example, Atiase, 1985; Brushan, 1989; Kasznik \& Lev, 1995; Parkash, Dhaliwal, \& Salatka, 1995).

Lastly, as proxies of financial risk, we considered the total debt to total assets ratio (DtoA), EBIT to interest expenses also known as the interest coverage ratio (ICR) and cash flow volatility (CFV). Cash flow volatility was computed as the coefficient of variation of cash flow obtained by dividing the standard deviation by the mean of annual cash flow from operations for the period 2009-2013 or, if not available, for a shorter period.

Data relating to the number of analysts were collected from the Italian stock exchange (Borsa Italiana, 2014) whilst market data and fundamentals were obtained from the Thomson Reuters databank.

In the first stage of the regression analysis, we used stock market indicators regardless of fundamentals in order to have a more homogeneous sample. In the second stage, the regression analysis was carried out using a subsample of 130 non-financial firms. Although raw data were collected over time, the correlation did not use time series data itself, but examined the reliability level of stock recommendations as defined in equation (1) and the average value of the above-mentioned explanatory variables in a cross-sectional regression. The correlation matrix of the variables examined is presented in Table 2. Panel A shows correlations of variables used in the first stage of the regression analysis related to the entire sample of 5,443 analysts' stock recommendations for 154 firms. Panel B presents correlations related to the subsample of 4,620 analysts' stock recommendations for the 130 non-financial firms. The results confirm the absence of the multicollinearity problem. The Variable Inflation Factor (VIF) was also used to test the multicollinearity.

Table 2. Correlation matrix

\begin{tabular}{|c|c|c|c|c|c|c|c|}
\hline Panel A & LogSTV & Beta & NA & & & & VIF \\
\hline LogSTV & 1 & & & & & & 1.690 \\
\hline Beta & 0.3776 & 1 & & & & & 1.220 \\
\hline NA & 0.5278 & 0.0338 & 1 & & & & 1.450 \\
\hline Panel B & ROA & ICR & $\mathrm{CFV}$ & $\log \mathrm{TA}$ & DtoA & MB & VIF \\
\hline ROA & 1 & & & & & & 1.662 \\
\hline ICR & 0.5664 & 1 & & & & & 1.544 \\
\hline $\mathrm{CFV}$ & -0.0602 & -0.0078 & 1 & & & & 1.001 \\
\hline $\log \mathrm{TA}$ & 0.0678 & -0.1168 & -0.0288 & 1 & & & 1.153 \\
\hline DtoA & -0.3862 & -0.3052 & 0.0195 & 0.2408 & 1 & & 1.283 \\
\hline MB & 0.2018 & 0.2258 & -0.0302 & -0.187 & -0.1853 & 1 & 1.103 \\
\hline
\end{tabular}




\section{Results}

Panel A of Table 3 presents the descriptive statistics of stock returns for the sample of 154 firms. Research findings revealed that the mean and the median of the absolute stock returns differ depending on whether they are positive, neutral or negative recommendations (respectively $1.74 \%$ and $0.75 \%$ for positive recommendations, $1.23 \%$ and $-0.21 \%$ for neutral recommendations, $0.64 \%$ and $-0.49 \%$ for negative recommendations), whilst the values of standard deviation increased, with the highest value for negative recommendations. A possible explanation for these results is that stock recommendations can on average forecast stock prices and the predictions appear to be more accurate in the case of positive recommendations compared with negative recommendations, as suggested by the increasing value of standard deviations. Although these results validate the reliability of stock recommendations, only a part of the analysts' forecasts is confirmed by stock returns. As shown in Panel B of Table 3, 55.1\% of positive recommendations were able to forecast a positive stock return and $53 \%$ of negative recommendations predicted a negative stock return. It is quite obvious that these results reflect almost a random guess. Panel B of Table 3 provides more details about the frequency distribution of absolute stock returns. We also analysed the reliability level of stock recommendations for each firm as defined in equation (1). Table 4 shows the level of reliability for positive and/or negative stock recommendations for the whole sample of 154 firms. In particular, the reliability levels of the positive and negative stock recommendations are normally distributed around the mean of $54 \%$ whilst the median assumes a value of about $55.5 \%$. In line with the findings illustrated above, these results show that only 84 firms, about $55 \%$ of our firm sample, had a level of reliability greater than the mean.

Table 3. Descriptive statistics of stock returns

\begin{tabular}{|c|c|c|c|c|c|c|c|c|c|}
\hline \multirow[t]{2}{*}{ Panel A } & \multicolumn{9}{|c|}{ Stock recommendations } \\
\hline & \multicolumn{3}{|c|}{ Positive } & \multicolumn{3}{|c|}{ Neutral } & \multicolumn{3}{|c|}{ Negative } \\
\hline \multicolumn{10}{|l|}{ Stock returns: } \\
\hline Mean & \multicolumn{3}{|c|}{$1.74 \%$} & \multicolumn{3}{|c|}{$1.23 \%$} & \multicolumn{3}{|c|}{$0.64 \%$} \\
\hline Median & \multicolumn{3}{|c|}{$0.75 \%$} & \multicolumn{3}{|c|}{$-0.21 \%$} & \multicolumn{3}{|c|}{$-0.49 \%$} \\
\hline St.Deviation & \multicolumn{3}{|c|}{$12.19 \%$} & \multicolumn{3}{|c|}{$15.40 \%$} & \multicolumn{3}{|c|}{$17.54 \%$} \\
\hline \multirow[t]{3}{*}{ Panel B } & \multicolumn{9}{|c|}{ Stock recommendations } \\
\hline & \multicolumn{3}{|c|}{ Positive } & \multicolumn{3}{|c|}{ Neutral } & \multicolumn{3}{|c|}{ Negative } \\
\hline & Unit & $\%$ & Cum \% & Unit & $\%$ & Cum \% & Unit & $\%$ & Cum $\%$ \\
\hline \multicolumn{10}{|l|}{ Stock returns: } \\
\hline Less than $(60 \%)$ & 1 & $0.03 \%$ & & 2 & $0.12 \%$ & & 2 & $0.40 \%$ & \\
\hline$(60 \%)-(40 \%)$ & 7 & $0.22 \%$ & & 5 & $0.29 \%$ & & 6 & $1.19 \%$ & \\
\hline$(40 \%)-(20 \%)$ & 54 & $1.67 \%$ & & 58 & $3.41 \%$ & & 23 & $4.56 \%$ & \\
\hline$(20 \%)-(10 \%)$ & 208 & $6.42 \%$ & & 152 & $8.95 \%$ & & 60 & $11.90 \%$ & \\
\hline$(10 \%)-0 \%$ & 1185 & $36.57 \%$ & $44.9 \%$ & 661 & $38.91 \%$ & $51.7 \%$ & 176 & $34.92 \%$ & $53 \%$ \\
\hline $0 \%-10 \%$ & 1340 & $41.36 \%$ & & 543 & $31.96 \%$ & & 145 & $28.77 \%$ & \\
\hline $10 \%-20 \%$ & 301 & $9.29 \%$ & & 164 & $9.65 \%$ & & 49 & $9.72 \%$ & \\
\hline $20 \%-40 \%$ & 112 & $3.46 \%$ & & 89 & $5.24 \%$ & & 33 & $6.55 \%$ & \\
\hline $40 \%-60 \%$ & 18 & $0.56 \%$ & & 15 & $0.88 \%$ & & 4 & $0.79 \%$ & \\
\hline $60 \%-80 \%$ & 6 & $0.19 \%$ & & 3 & $0.18 \%$ & & 3 & $0.60 \%$ & \\
\hline More than $80 \%$ & 8 & $0.25 \%$ & $55.1 \%$ & 7 & $0.41 \%$ & $48.3 \%$ & 3 & $0.60 \%$ & $47 \%$ \\
\hline Total & 3240 & $100 \%$ & $100 \%$ & 1699 & & $100 \%$ & 504 & & $100 \%$ \\
\hline
\end{tabular}

The regression analysis was therefore performed assuming the reliability level of the overall positive and negative stock recommendations computed for each firm according to equation (1) as the dependent variable (firms with reliable stock recommendations $\mathrm{Y}=1$; firms with unreliable stock recommendations $\mathrm{Y}=0$ ) and some average market indicators and financial ratios as explanatory variables. The results of logistic regression according to model (2) are shown in Table 5.

The first step of the logistic regression focused on the average stock market indicators as defined in section 3 . The research findings presented in Panel A of Table 5 indicate that the probability of having firms with reliable stock recommendations increases as the beta coefficient (Beta) decreases. The strong correlation suggests that volatility, measured by the firm's beta, is a valid predictor of the accuracy of stock recommendations. The regression analysis did not reveal any statistical significance for the daily stock trading volume (LogSTV) and 
the number of analysts that covered the firms (NA). The second step of the logistic regression involved the average financial ratios for the subsample of 130 non-financial firms. As shown in panel B of Table 5, the regression revealed the existence of a positive correlation between the level of reliability and the interest coverage ratio (ICR). In other words, the ability of firms to pay interest on outstanding debt with their revenues allows brokerage houses to provide more accurate stock recommendations. Furthermore, the regression analysis showed that the probability of having reliable stock recommendations increases as the cash flow volatility (CFV) decreases, as indicated by the negative value of the coefficient of variation of cash flow.

Table 4. Reliability of stock recommendations

\begin{tabular}{|c|c|c|c|c|c|c|}
\hline & \multicolumn{6}{|c|}{ Stock recommendations } \\
\hline & \multicolumn{2}{|c|}{ Positive } & \multicolumn{2}{|c|}{ Negative } & \multicolumn{2}{|c|}{ Positive and Negative } \\
\hline & Firms & $\%$ & Firms & $\%$ & Firms & $\%$ \\
\hline \multicolumn{7}{|c|}{ Level of reliability: } \\
\hline $0-10 \%$ & 7 & $4.5 \%$ & 12 & $7.8 \%$ & 3 & $1.9 \%$ \\
\hline $10 \%-20 \%$ & 5 & $3.2 \%$ & 1 & $0.6 \%$ & 3 & $1.9 \%$ \\
\hline $20 \%-30 \%$ & 7 & $4.5 \%$ & 5 & $3.2 \%$ & 6 & $3.9 \%$ \\
\hline $30 \%-40 \%$ & 18 & $11.7 \%$ & 5 & $3.2 \%$ & 20 & $13.0 \%$ \\
\hline $40 \%-50 \%$ & 27 & $17.5 \%$ & 11 & $7.1 \%$ & 26 & $16.9 \%$ \\
\hline $50 \%-60 \%$ & 38 & $24.7 \%$ & 9 & $5.8 \%$ & 45 & $29.2 \%$ \\
\hline $60 \%-70 \%$ & 27 & $17.5 \%$ & 6 & $3.9 \%$ & 30 & $19.5 \%$ \\
\hline $70 \%-80 \%$ & 8 & $5.2 \%$ & 3 & $1.9 \%$ & 10 & $6.5 \%$ \\
\hline $80 \%-90 \%$ & 6 & $3.9 \%$ & 2 & $1.3 \%$ & 4 & $2.6 \%$ \\
\hline More $90 \%$ & 5 & $3.2 \%$ & 9 & $5.8 \%$ & 5 & $3.2 \%$ \\
\hline n.a.* & 6 & $3.9 \%$ & 91 & $59.1 \%$ & 2 & $1.3 \%$ \\
\hline Total & 154 & & 154 & & 154 & \\
\hline
\end{tabular}

Note. $*$ Stock recommendations not available for the specified class of ratings.

Table 5. Reliability of stock recommendations and regression results

\begin{tabular}{|c|c|c|c|c|c|}
\hline Panel A & Estimate & Std Error & $\mathrm{z}$ value & $\operatorname{Pr}(>|z|)$ & \\
\hline Const & 0.928842 & 0.467723 & 1.9859 & 0.04705 & $* *$ \\
\hline Log Stock trading volume (LogSTV) & -0.0990498 & 0.200727 & -0.4935 & 0.62169 & \\
\hline Beta coefficient (Beta) & -1.08139 & 0.413396 & -2.6159 & 0.00890 & $* * *$ \\
\hline Number of analysts (NA) & 0.0634223 & 0.0778028 & 0.8152 & 0.41498 & \\
\hline Panel B & Estimate & Std Error & $\mathrm{z}$ value & $\operatorname{Pr}(>|z|)$ & \\
\hline Const & 0.651638 & 0.887752 & 0.7340 & 0.46293 & \\
\hline Return on assets ratio (ROA) & -0.448037 & 3.15542 & -0.1420 & 0.88709 & \\
\hline Interest coverage ratio (ICR) & 0.0202323 & 0.0111783 & 1.8100 & 0.07030 & $*$ \\
\hline Cash flow volatility (CFV) & -0.462226 & 0.258679 & -1.7869 & 0.07396 & * \\
\hline Log Total assets (LogTA) & -0.125592 & 0.227605 & -0.5518 & 0.58109 & \\
\hline Total debt to total assets (DtoA) & 0.337311 & 1.39455 & 0.2419 & 0.80887 & \\
\hline Market to book ratio (MB) & -0.0888563 & 0.133487 & -0.6657 & 0.50563 & \\
\hline
\end{tabular}

Note. *** Significant at the 0.01 level, ** Significant at the 0.05 level, * Significant at the 0.10 level (two-tailed).

These results suggest that the level of reliability is associated with the uncertainty faced by investors who hold stocks in a specific firm. Market risk measured by firm's beta (Beta) and financial risk measured by the interest coverage ratio (ICR) and cash flow volatility (CFV) are negatively associated with the reliability of stock recommendations. Although our analysis focused on stock recommendations rather than on the accuracy of earnings forecasts, the present findings seem to be consistent with other research which outlined that uncertainty in earnings forecasts is positively correlated to financial risk (Parkash, Dhaliwal, \& Salatka, 1995). On the contrary, our research findings differ from other studies that did not find a significant explanatory power of the firm's beta (Jaggi \& Jain, 1998) and those that have identified a correlation between the accuracy of earnings forecasts and the number of analysts studying a firm (Parkash, Dhaliwal, \& Salatka, 1995). 


\section{Conclusions}

This paper has analysed a sample of 5,443 stock recommendations issued by brokerage houses on 154 companies listed on the Italian stock exchange between 2009 and 2013 in order to verify whether stock recommendations are confirmed by absolute stock returns and which firm-specific characteristics can explain the different level of reliability of stock recommendations for each firm.

Two main findings emerge from the present research. First, descriptive statistics revealed a limited ability of stock recommendations to forecast absolute stock returns. Although the mean and the median of absolute stock returns following recommendations differ depending on positive, neutral and negative recommendations, research findings showed that a portion just over $50 \%$ of positive and negative recommendations were confirmed by absolute stock returns and that the level of reliability of stock recommendations for each firm are normally distributed around the mean of 54\%. Second, explanatory variables which are statistically significant for the level of reliability seem to be connected in different ways to the uncertainty faced by investors who hold stocks in a specific firm. The reduction in uncertainty, as revealed by the positive value of the interest coverage ratio and the negative estimate of the firm's beta and cash flow volatility, is associated with the increasing level of reliability of stock recommendations for each firm.

These results enhance our overall understanding about the role of stock recommendations in providing reliable forecasts. More specifically, the information about the reliability of stock recommendations can help unsophisticated investors who are interested in absolute stock returns to improve their decision-making. Likewise, research findings may also be useful to firms in analysing investors' behaviour in order to optimize their financial policy.

\section{References}

Abarbanell, J., \& Lehavy, R. (2003). Can stock recommendations predict earnings management and analysts' earnings forecast errors? Journal of Accounting Research, 4l(1), 1-31. http://dx.doi.org/10.1111/1475-679X.00093

Atiase, R. K. (1985). Predisclosure information, firm capitalization, and security price behaviour around earnings announcements. Journal of Accounting Research, 23(1), 21-36. http://dx.doi.org/10.2307/2490905

Bagnoli, M., Clement, M. B., Crawley, M. J., \& Watts, S. G. (2009). The Profitability of Analysts' Stock Recommendations: What Role Does Investor Sentiment Play? Retrieved from http://ssrn.com/abstract=1430617

Bandyopadhyay, S. P., Brown, L. D., \& Richardson, G. D. (1995). Analysts' use of earnings forecasts in predicting stock returns: Forecast horizon effects. International Journal of Forecasting, 11, 429-445. http://dx.doi.org/10.1016/0169-2070(95)00593-0

Barber, B., Lehavy, R., McNichols, M., \& Trueman, B. (2001). Can investors profit from the prophets? Security analysts' recommendations and stock returns. The Journal of Finance, 56(2), 531-563. http://dx.doi.org/10.1111/0022-1082.00336

Barber, B., Lehavy, R., McNichols, M., \& Trueman, B. (2006). Buys, holds, and sells: The distribution of investment banks' stock ratings and the implications for the profitability of analysts' recommendations. Journal of Accounting and Economics, 41, 87-117. http://dx.doi.org/10.1016/j.jacceco.2005.10.001

Barniv, R., Hope, O. K., Myring, M., \& Thomas, W. B. (2010). International evidence on analyst stock recommendations, valuations, and returns. Contemporary Accounting Research, 27(4), 1131-1167. http://dx.doi.org/10.1111/j.1911-3846.2010.01036.x

Bhushan, R. (1989). Firm characteristics and analyst following. Journal of Accounting and Economics, 11(2-3), 255-274. http://dx.doi.org/10.1016/0165-4101(89)90008-6

Bidwell, C. (1977). How good is institutional brokerage research. Journal of Portfolio Management, 3, 26-31. http://dx.doi.org/10.3905/jpm.1977.26.

Borsa Italiana. (2014). Retrieved March, 2014, from http://www.borsaitaliana.it/azioni/azioni/azioni.htm

Bradshaw, M. T. (2002). The use of target prices to justify sell-side analysts' stock recommendations. Accounting Horizons, 16(1), 27-41. http://dx.doi.org/10.2308/acch.2002.16.1.27.

Bradshaw, M. T. (2004). How do analysts use their earnings forecasts in generating stock recommendations? The Accounting Review, 79(1), 25-50. http://dx.doi.org/10.2308/accr.2004.79.1.25

Cavezzali, E., Crepaldi, J., \& Rigoni, U. (2014). Proximity to hubs of expertise and financial analyst forecast 
accuracy. Eurasian Business Review, 4, 157-179. http://dx.doi.org/10.1007/s40821-014-0007-8

Chan, H. W. H., Brown, R., \& Ho, Y. K. (2006). Initiation of brokers' recommendations, market predictors and stock returns. Journal of Multinational Financial Management, 16, 213-231. http://dx.doi.org/10.1016/j.mulfin.2005.07.004

Chang, Y. H., \& Chan, C. C. (2008). Financial analysts' stock recommendation revisions and stock price changes. Applied Financial Economics, 18, 309-325. http://dx.doi.org/10.1080/09603100600606131

Chen, C. Y., \& Chen, P. F. (2009). NASD Rule 2711 and changes in analysts' independence in making stock recommendations. The Accounting Review, 84(4), 1041-1071. http://dx.doi.org/10.2308/accr.2009.84.4.1041

Chiang, H. T., \& Chia, F. (2005). Analyst's financial forecast accuracy and information transparency. The Journal of American Academy of Business, Cambridge, 7(2), 164-167.

Choi, K., Chen, X., Wright, S., \& Wu, H. (2014). Analysts' forecasts following forced CEO changes. ABACUS, 50(2), 146-173. http://dx.doi.org/10.1111/abac.12026

Dhaliwal, D. S., Radhakrishnan, S., Tsang, A., \& Yang, Y. G. (2012). Nonfinancial disclosure and analyst forecast accuracy: International evidence on corporate social responsibility disclosure. The Accounting Review, 87(3), 723-759. http://dx.doi.org/10.2308/accr-10218

Elton, E. J., Gruber, M. J., \& Grossman, S. (1986). Discrete expectational data and portfolio performance. The Journal of Finance, 16(3), 699-713. http://dx.doi.org/10.1111/j.1540-6261.1986.tb04534.x

Erdogan, O., Palmon, D., \& Yezegel, A. (2011). Performance of analyst recommendations in the Istanbul Stock Exchange. International Review of Applied Financial Issues and Economics, 3(3), 491-503.

Ertimur, Y., Sunder, J., \& Sunder, S. V. (2007). Measure for measure: The relation between forecast accuracy and recommendation profitability of analysts. Journal of Accounting Research, 45(3), 567-606. http://dx.doi.org/10.1111/j.1475-679X.2007.00244.x

Francis, J., \& Soffer, L. (1997). The relative informativeness of analysts' stock recommendations and earnings forecast revisions. Journal of Accounting Research, 35(2), 193-211. http://dx.doi.org/10.2307/2491360

Irvine, P. J. (2004). Analysts' forecasts and brokerage-firm trading. The Accounting review, 79(1), 125-149. http://dx.doi.org/10.2308/accr.2004.79.1.125

Ivković, Z., \& Jegadeesh, N. (2004). The timing and value of forecast and recommendation revisions. Journal of Financial Economics, 73, 433-463. http://dx.doi.org/10.1016/j.jfineco.2004.03.002

Jacob, J., Rock, S., \& Weber, D. P. (2008). Do non-Investment bank analysts make better earnings forecasts? Journal of Accounting, Auditing \& Finance, 23(1), 23-61.

Jaggi, B., \& Jain, R. (1998). An evaluation of financial analysts' earnings forecasts for Hong Kong firms. Journal of International Financial Management and Accounting, 9(3), 177-200. http://dx.doi.org/10.1111/1467-646X.00036

Jegadeesh, N., \& Kim, W. (2006). Value of analyst recommendations: International evidence. Journal of Financial Markets, 9, 274-309. http://dx.doi:10.1016/j.finmar.2006.05.001

Jegadeesh, N., \& Kim, W. (2010). Do analysts herd? An analysis of recommendations and market reactions. The Review of Financial Studies, 23(2), 901-937. http://dx.doi.org/10.1093/rfs/hhp093

Jegadeesh, N., Kim, J., Krische, S. D., \& Lee, C. M. C. (2004). Analyzing the analysts: When do recommendations add value? The Journal of Finance, 49(3), 1083-1124. http://dx.doi.org/10.1111/j.1540-6261.2004.00657.x

Kanagaretnam, K., Lobo, G. J., \& Mathieu, R. (2012). CEO stock options and analysts' forecast accuracy and bias. Review of Quantitative Finance and Accounting, 38, 299-322. http://dx.doi.org/10.1007/s11156-011-0229-0

Kasznik, R., \& Lev, B. (1995). To Warn or Not to Warn: Management Disclosures in the Face of an Earnings Surprise. The Accounting Review, 70(1), 113-134

Liang, L., \& Riedl, E. J. (2014). The effect of fair value versus historical cost reporting model on analyst forecast accuracy. The Accounting Review, 89(3), 1151-1177. http://dx.doi.org/10.2308/accr-50687

Lidén, E. R. (2007). Swedish stock recommendations: information content or price pressure? Multinational 
Finance Journal, 11(3/4), 253-285.

Lin, W. Y., Chen, P. J., \& Chen, S. S. (2011). Stock characteristics and herding in financial analyst recommendations. Applied Financial $\quad$ Economics, $21, \quad$ 317-331. http://dx.doi.org/10.1080/09603107.2010.528367

Lin, H. W., \& McNichols, M. F. (1998). Underwriting relationships, analysts' earnings forecasts and investment recommendations. Journal of Accounting and Economics, 25, 101-127. http://dx.doi.org/10.1016/S0165-4101(98)00016-0

Logue, D. E., \& Tuttle, D. L. (1973). Brokerage house investment advice. Financial Review, 8, 38-54. http://dx.doi.org/10.1111/j.1540-6288.1973.tb01440.x

Loh, R. K., \& Mian, G. M. (2006). Do accurate earnings forecasts facilitate superior investment recommendations? Journal of Financial Economics, $80, \quad 455-483$. http://dx.doi:10.1016/j.jfineco.2005.03.009

Lustgarten, S., \& Tag, C. (2008). Analysts' heterogeneous earnings forecasts and stock recommendations. Journal of Accounting, Auditing \& Finance, 23(3), 377-401.

Malmendier, U., \& Shanthikumar, D. (2007). Are small investors naïve about incentives? Journal of Financial Economics, 85(5), 457-489. http://dx.doi.org/10.1016/j.jfineco.2007.02.001

Mauri, A. J., Lin, J., \& De Figueiredo, J. N. (2013). The influence of strategic patterns of internationalization on the accuracy and bias of earnings forecasts by financial analysts. International Business Review, 22, 725-735. http://dx.doi.org/10.1016/j.ibusrev.2012.11.002

Menéndez-Requejo, S. (2005). Market valuation of the analysts' recommendations: The Spanish stock market. Applied Financial Economics, 15, 509-518. http://dx.doi.org/10.1080/09603100500056585

Michaely, R., \& Womak, K. L. (1999). Conflict of interest and the credibility of underwriter analyst recommendations. Review of Financial Studies, 12(4), 653-686. doi.org/10.1093/rfs/12.4.653

Mikhail, M. B., Walther, B. R., \& Willis, R. H. (2007). When security analysts talk, who listens? The Accounting Review, 82(5), 1227-1253. http://dx.doi.org/10.2308/accr.2007.82.5.1227

Mokoaleli-Mokoteli, T., Taffler, R. J., \& Agarwal, V. (2009). Behavioural bias and conflicts of interest in analyst stock recommendations. Journal of Business Finance \& Accounting, 36(3/4), 384-418. http://dx.doi.org/10.1111/j.1468-5957.2009.02125.x

Nowland, J., \& Simon, A. (2010). The effect of a change in analyst composition on analyst forecast accuracy: Evidence from U.S. cross-listings. Journal of International Accounting Research, 9(1), 23-38. http://dx.doi.org/10.2308/jiar.2010.9.1.23

Parkash, M., Dhaliwal, D. S., \& Salatka, W. K. (1995). How certain firm-specific characteristics affect the accuracy and dispersion of analysts' forecasts: A latent variables approach. Journal of Business Research, 34(3), 161-169. http://dx.doi.org/10.1016/0148-2963(94)00076-Q

Schlumpf, P. M., Schmid, M. M., \& Zimmermann, H. (2008). The first- and second-hand effect of analysts' stock recommendations: Evidence from the Swiss stock market. European Financial Management, 14(5), 962-988. http://dx.doi.org/10.1111/j.1468-036X.2007.00435.x

Shen, C. H., \& Chih, H. L. (2009). Conflicts of interest in the stock recommendations of investment banks and their determinants. Journal of Financial and Quantitative Analysis, 44(5), 1149-1171. http://dx.doi.org/10.1017/S002210900999024X

Stickel, S. E. (1995). The anatomy of the performance of buy and sell recommendations. Financial Analysts Journal, 51(5), 25-39. http://dx.doi.org/10.2469/faj.v51.n5.1933

Womack, K. L. (1996). Do brokerage analysts' recommendations have investment value? The Journal of Finance, 51(1), 137-167. http://dx.doi.org/10.1111/j.1540-6261.1996.tb05205.x

\section{Copyrights}

Copyright for this article is retained by the author(s), with first publication rights granted to the journal.

This is an open-access article distributed under the terms and conditions of the Creative Commons Attribution license (http://creativecommons.org/licenses/by/3.0/). 